\title{
The Information Desk: the Library's Gateway to Service
}

\begin{abstract}
Member libraries of the Association of Research Libraries were surveyed via a questionnaire to determine whether they had an Information Desk Librarian and, if so, the extent of services provided at such a reference point. The responses of the thirty-seven libraries offering this service were tabulated and formed the basis for ten guidelines listed at the conclusion of this study. It was hoped that these recommendations would be useful to libraries planning to establish this point of contact with the patron.
\end{abstract}

$\mathrm{U}$ NIVERSITY LIBRARIES today are experiencing the most rapid growth in their history. The publication explosion has resulted in the mushrooming acquisition of research material, a need for librarians to disseminate this material, and a resounding cry from library administrators for more and better facilities in which to house it.

These trends, greeted by some librarians with excitement and anticipation, have aroused negative feelings in others, for such an explosion in research can and does present many problems to academic libraries. Initially, these trends are increasing the complexities of providing good library service. Frequently, libraries, struggling under this tonnage of material, become so involved with the technical aspects of the problem that they possibly overlook the most important single factor of library service-the library user.

In considering the problems confronting university libraries in improving service to the user, it appears that the establishment of an information desk service would be an excellent means of providing more and better contact with the

Mrs. Kleiner is Interlibrary Loan Librarian in Louisiana State University. patron. Many university libraries throughout the country having recognized this fact are striving to develop a point of contact which will introduce the user into the areas of the library from which he can derive the most benefit. Others have not yet experienced the need for such a service or have not recognized the necessity for it.

Research in library information services has seemingly overlooked the area of the information desk. A thorough search of Library Literature reveals that no recent articles have considered this subject. Possibly, this lack of study of such an area is a primary reason for many libraries having failed to recognize the values of this initial point of contact between the library and the user. This study hopes to focus attention on the possibilities of this service-a service which may have many names. For the purpose of this paper, it shall be referred to as the information desk.

In an effort to determine how many libraries had already instituted such a procedure, and the guidelines used for establishing the service, a questionnaire was devised and forwarded to seventythree member libraries of the Association of Research Libraries. These libraries 


\section{How is it staffed?}

Librarians

Library assistants

Clerical employees

4. Is the desk staffed by:

One person on a full-time basis

Personnel alternating the hours

5. How many hours is it open daily?

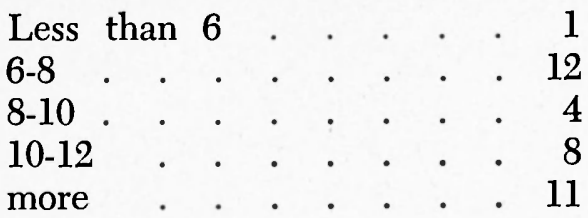

The average hours of daily service proved to be nine. One library reported sixteen hours of service at this position.

6. Is simple reference service provided at this desk?

$$
\text { Yes . . . . . . . } 26
$$$$
\text { No . . . . . . . } 10
$$

7. How many reference books are kept at the desk?

$$
\begin{aligned}
& \text { None . . . . . } 15 \\
& 5-10 \text {. . . . . . } 3 \\
& 10-25 \text {. . . . . } 6 \\
& 30-60 \text {. . . . . . . } 1 \\
& 70-100 \text {. . . . . . . } 2 \\
& \text { more than } 100 \text {. . . . . } 10
\end{aligned}
$$

Such a variety in the number of reference items housed at the desk indicates the extremes in reference provided by the participating libraries, running the gauntlet from absolutely no reference assistance to a considerable degree of it. Also, it should be pointed out that five of the fifteen libraries which reported no collection at the desk, stated they were in proximity to a reference collection and did not see the need for maintaining the tools at the desk. Hence, an average of ten to twenty-five books, based on a tabulation of the various sizes of the col- lections rather than the number of libraries now having such a collection, seems to be the recommended number.

8. Are brochures, pamphlets, handbooks, maps distributed to the public at the desk?

$$
\begin{aligned}
& \text { Yes . . . . . } 28 \\
& \text { No . . . . . . . . } 9
\end{aligned}
$$

9. Does your library have a telephone switchboard?

$$
\begin{aligned}
& \text { Yes . . . . . } 9 \\
& \text { No . . . . . . . } 28
\end{aligned}
$$

10. If no, does your information desk handle all incoming general library calls?

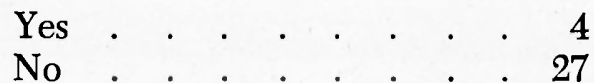

Some libraries felt they could not give an unqualified reply to this question. Therefore, six refrained from giving a direct answer.

11. Is simple telephone reference service provided at this desk?

Yes

No

12. Does your information desk staff member have any public relations duties, such as conducting tours, speaking to groups on library orientation, etc?

$$
\text { Yes . . . . . . . } 19
$$$$
\text { No . . . . . . . } 18
$$

The opinions on this question seemed to be more divided than on any other in the questionnaire, and this is possibly as it should be. Whether or not the information desk librarian should have such duties can only be determined by the capabilities of the person filling this position.

13. An information desk attendant usually provides three types of informa- 
tion: directional (where is such and such); instructional (use of card catalog and library); simple reference (either by phone or in person).

The libraries were then asked to provide an estimate as to the percentage of these types of questions answered at the desk, basing their percentage estimates on a 100 per cent total. This question provided the most problems in determining the manner in which to list the replies. In tabulating the estimates provided for this question, it appeared that for the percentages to be meaningful, it was necessary to present them in three different categories. It should also be pointed out here that although earlier in the questionnaire ten libraries stated that they offered absolutely no reference service at this desk, when asked to provide statistics, only six of the ten entered a 0 percentage on the statistical division. Also, it should be noted that the following statistics are based on those provided by only thirty- six of the thirty-seven libraries having information desks, as one failed to respond to this question.

An average of all of the thirty-six participating libraries estimated percentages follows:

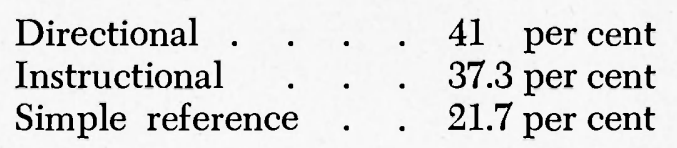

The following percentages exclude the six libraries having information desks, but not providing any reference service:

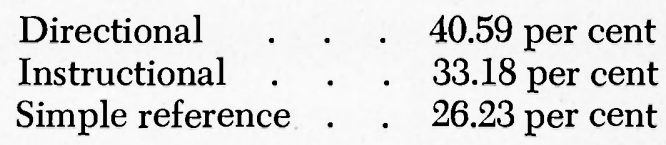

It also seemed that, with the figures available, it would be interesting to show the division of questions in libraries which appear to be making full use of their information desk service. To arrive at this figure, the nine libraries which reported less than 10 per cent reference questions were excluded along with the

\section{LIBRARIES MAINTAINING INFORMATION DESKS}

Boston Public Library

Boston University Library

University of Colorado Library

Harvard University Library

University of Illinois Library

University of Kentucky Library

Louisiana State University Library

University of Maryland Library

McGill University Library

Michigan State University Library

University of Michigan Library

University of Nebraska Library

University of Missouri Library

National Agricultural Library

National Library of Medicine

The Newberry Library

New York Public Library

Northwestern University Library

University of Notre Dame Library
Ohio State University Library

University of Oklahoma Library

Oklahoma State University Library

University of Pennsylvania Library

Pennsylvania State University Library

Princeton University Library

Purdue University Library

University of Rochester Library

University of Southern California Library

Syracuse University Library

University of Texas Library

Texas A \& M University Library

University of Toronto Library

University of Utah Library

University of Virginia Library

University of Washington Library

Wayne State University Library

University of Wisconsin Library 
aforementioned six. The percentages on this basis follow:

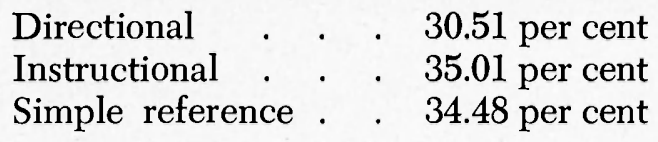

A study of these figures indicated that 59 per cent of the libraries having information desks are making full use of the potential such a service offers. The remaining 41 per cent have not yet recognized the extent to which such desks may be used to serve the patron. And 16 per cent of this latter division are merely using the desk as a directional device.

14. Bearing in mind the type information provided by this desk, what do you believe the occupational status of the attendant should be?

Librarian
Library assistant
Clerical $\cdot$
Two libraries did not specify.

The responses to this question showed that there was little variation in the present staffing of the position from what would be preferred. A comparison of the preferences shown here to the actual staffing policies revealed in question 3 substantiates this statement.

With the growth of the university student body, constantly on the climb because of the continuing population explosion, it appears that university libraries are going to be increasingly pushed to make provisions for such a service as the information desk. And, in considering the establishment of such a service in the library, its assets, not only to the students but to new faculty members, cannot be overlooked. The initial contact by the information desk librarian with new faculty members can create an improved climate for cooperation between the library and the faculty which is so important to good academic relationships.

Bearing these ideas in mind and also the compilation of information obtained from the questionnaire, it seemed that this study would not be complete without the formulation of tentative guidelines for the establishment of such a facility. Recommendations for such guidelines follow.

1. The information desk should be located near the card catalog which is preferably situated adjacent to the main lobby of the library.

2. It should be staffed by librarians.

3. An information desk librarian should be named to supervise the service, but should not be expected to devote the thirty-five- to forty-hour work week to this position. Such a librarian could be in the reference department in another area of the library, but that librarian should be responsible for the smooth operation of this service which is, after all, an extension of reference.

4. The information desk librarian should personally staff the desk at specified hours, but the remainder of the desk's hours should be alternated with other librarians. The length of time spent at the desk must be determined by the staff available at the library initiating the service.

5. The desk should be staffed a minimum of nine hours daily. These hours need not be in succession but should be arranged to provide service during peak hours.

6. Simple reference should be provided at this desk if it is to fulfill its function as a useful library service. Depending upon its proximity to the general reference desks, this should be supported by a collection of from ten to twentyfive very carefully selected reference tools. This small collection should be frequently scrutinized to insure that the librarian is able to provide a maximum 
of service from a minimal collection. Deadwood must not be allowed to collect.

7. Brochures, pamphlets, handbooks, maps, or any other literature concerning the library should be distributed at this point.

8. The information desk is not a telephone switchboard for the library and should not be used as such. The telephone duties might naturally include a number of misdirected calls, however; this occurs in all parts of the library. It should be a part of the information desk librarian's duties to direct the callers to the proper department.

9. Simple telephone reference service and card catalog information should be provided here. More difficult reference questions can be referred to the proper area from this point.

10. The librarian who is assigned the position of supervising the information desk should be a person qualified in the area of public relations. The library should always bear in mind that the information desk is frequently the first point of contact with student and faculty and that first impressions, if unfortunate, are often difficult to dispel. Such a person should be able to conduct tours and to speak to groups on library orientation. The first duty of the information desk librarian is to inform the patron, and this librarian should be suited to such a role. 